\title{
Encoding focus in Kanuri verbal morphology: Predication focus and the "Kanuri focus shift"
}

\author{
H. Ekkehard Wolff \\ Doris Löhr \\ Institute for African Studies, University of Leipzig
}

Focus on verbal operators such as aspect or tense ("predication focus", lucidly described by Hyman \& Watters (1984) under the label "auxiliary focus") has been noticed to exist in African languages of Afroasiatic and Niger-Congo affiliation, but not so far in Saharan. The Saharan language Kanuri is assumed to have substantially reorganized its TAM system, particularly in the perfective aspect domain (Cyffer [2006] dates major changes between the years 1820 and 1900). The paper discusses, for the first time in Kanuri scholarship, the existence of a neat subsystem of predication focus marking by suffix in the perfective aspect which is made up of a total of six conjugational paradigms that uniformly encode predication focus by suffix \{-ò\}. Kanuri dialects differ in strategies and scope of focus marking encoded in verb morphology. In the light of data from the Yerwa (Nigeria) and Manga (Niger) dialects the paper discusses some "anomalies" with regard to general focus theory which we account for by describing the "Kanuri Focus Shift" as a diachronic process which is responsible for leftward displacement of scope of focus.

\section{Introduction}

Focus on verbal operators such as aspect or tense was noticed to exist in African languages of Afroasiatic (Chadic) and Niger-Congo (Atlantic, [New] BenueCongo, [New] Kwa) genealogical affiliation for quite some time. The syntactosemantic and morphological properties involved had been described under rather non-consistent terminology in more traditional descriptions, such as "absolute"

1 The authors gratefully acknowledge valuable comments on previous versions of the paper by Norbert Cyffer, John Hutchison, Kevin Jarrett, Klaus Schubert, Dmitry Bondarev and by the editors. For checking data from the literature and elicitation of Manga data in particular, we thank Elhadji Ari Awagana, a linguistically trained mother-tongue speaker of the Manga variety, for the inspiring cooperation. All responsibility for shortcomings of analysis and presentation remains with us. 
vs. "relative" aspects or tenses. The first unifying account was given under the notion of "auxiliary focus" in the seminal paper by Hyman \& Watters (1984). More recently, some Chadic languages (including Hausa, cf. Wolff 2006 and Malgwa, cf. Löhr, in press), have been subjected to reanalyses of their verbal inflexional systems, following up on the pioneer approach by Hyman \& Watters (1984), identifying predication focus (synonymous with Hyman \& Watters' "auxiliary focus") as an important non-canonical inflexional category. In particular, the relevance of notions such as "inherent focus" and "focus control" were discussed for several Chadic languages (Wolff 2003, 2006), and also the intriguing interface with polarity (Wolff, in press). In the light of this work on the Chadic languages spoken in the Chadic-Saharan contact area of NorthEastern Nigeria, the authors set out to explore the hypothesis of potential typological convergence in Kanuri, which is a Saharan language of Nilosaharan genealogical affiliation, and some Chadic languages, which are of ultimately of Afroasiatic genealogical affiliation, in what can be roughly identified as their geographic contact area to the west of Lake Chad. A detailed discussion of whether and how the Kanuri grammatical system testifies to interference from Chadic substrata (and/or vice versa) will, however, be provided elsewhere (cf. Wolff and Löhr, in prep).

\section{Theoretical and methodological preliminaries}

The Kanuri system of TAM marking has intrigued scholars for more than 150 years. The competing terminologies and various functional labels that have been used in the descriptions are indicative of the morphological, syntactic and semantic challenges that the Kanuri verbal inflexion system pose for analysis. In particular, labels such as predicative, relational, verb emphasis past vs. noun emphasis past etc. are quite suspicious of involving focus categories that would be worth revisiting in terms of more recent insights into the study of information structure in (West) African languages. Following up on Hyman \& Watters (1984) who had not considered Kanuri nor any other Chadic language apart from Hausa, the question the authors set out to answer was the following: Can the notion of predication focus (= Hyman \& Watters' "auxiliary focus") and some of the current cross-linguistic generalisations regarding focus be used to shed more light on the semanto-syntactic and morphological intricacies of verbal inflexion in Kanuri? In the light of the long history and in-depth nature of the available descriptions of the various conjugational paradigms provided by expert writers on the language, the starting point was to revisit their detailed descriptions and relate these to more recent typological and theoretical insights with regard to encoding information structure. Occasionally, Kanuri data were checked or newly elicited with a native speaker. 
The paper will not discuss the notion of focus per se as a category that is generally accepted to highlight new or salient information within the clause (and beyond the clause), but is exclusively concerned with focus marking, in particular with morphological marking on the verb. Given the intricate relationship with the likewise morphologically marked categories of aspect and tense, marking focus on the verb will be treated as part of verbal inflexional morphology. For clarity and ease of reference in the description of Kanuri, therefore, we suggest drawing a distinction between canonical inflexional categories (such as aspect, tense, mood) and non-canonical inflexional categories (such as focus and, possibly, theticity, as well as syntactic dependency) which are all marked by inflexional morphology, at least in Kanuri.

Guided by our previous experience with the analysis, description, and typological comparison of grammatical systems that encode focus in verbal morphology (cf. Wolff 1983, 2003, 2006, in press; Löhr, in press), we start off by the following theoretical and methodological assumptions: ${ }^{2}$

- Taking the clause to provide the syntactic frame to start with, we accept that clauses may be internally structured in terms of salience or novelty of information (referred to as information structure $(=$ IS), in different schools of thought referred to as topic vs. comment, theme vs. rheme, new information vs. old information, functional sentence perspective etc.), but also that they may not. ${ }^{3}$ Accordingly, we consider clauses to be either marked for [+IS] (usually by default) or not, i.e. allow for special cases of [-IS] clauses (this will be referred to as theticity).

- We follow general focus theory by taking focus to be an IS category that specifically relates to salience or novelty of information in [+IS] clauses

2 Cf. Wolff (2003) for a more detailed presentation of the underlying theory on focus which is largely based on Hyman and Watters (1984) and also acknowledges Güldemann (1996). Much of the theoretical and methodological groundwork was laid under a generous grant (1995-98) by the Deutsche Forschungsgemeinschaft (in the Schwerpunktprogramm 'Sprachtypologie') which is gratefully acknowledged by H. E. Wolff.

3 Properties of information structure beyond the clause will not be considered here since we are mainly concerned with morphological marking of (assertive) predication focus whose domain we presently assume to be the clause. - The following abbreviations will be used: $1 / 2 / 3=$ first/second/third person, aff. = affirmative, AG = agent, APPL = applied, AUX = auxiliary verb root, $\mathrm{CO}=$ coordinator, $\mathrm{CPTP}=$ counter-presuppositional thetic perfect, dep. = dependent, DET = determiner, DFUT = dependent future, DIR = direction, DO = direct object, DPRET $=$ dependent preterite, ex./exx $=$ example(s), F/FOC $=$ focus, fut./FUT = future, GEN = genitive, IFP = in-focus perfect, IMPERF = imperfect, IO = indirect object, IS = information structure, $\mathrm{LOC}=$ locative, neg. $/ \mathrm{NEG}=$ negative, p.c. $=$ personal communication, $\mathrm{PERF}=$ perfect, $\mathrm{PF}=$ predication focus, $\mathrm{P} / \mathrm{pl} .=$ plural, $\mathrm{POSS}=$ possessive, pret./PRET $=$ preterite, $\mathrm{S} / \mathrm{sg} .=$ singular, $\mathrm{SP}=$ subject pronoun, $\mathrm{TF}=$ term focus. 
in the sense of highlighting the particular information component that the speaker assumes not be shared with the addressee. [+F] would indicate "new" or "salient" information components (in-focus components) and the expectation is that these information components are overtly marked in some way (prosodic, morphological, syntactic); [-F] would refer to those that are not highlighted (out-of-focus components).

- Clauses that can or must be assumed to be [-IS], could be interpreted in at least two different ways: They are either automatically devoid of any type of IS and focus (i.e. thetic), or one could argue that focus is on the whole clause (and hence speak of clause focus). For Kanuri we tentatively follow the thetic interpretation. ${ }^{4}$

- For focus we will distinguish two basic functional types: assertive focus (with the function of highlighting an information component that is overtly expressed in the clause) and contrastive focus (with the function of relating the highlighted information component to extra-clausal context)..$^{5}$

- For focus, we will further distinguish different scopes of the feature [+F]: Predication focus has scope on predicative operators, such as aspect,

4 Hence we make use of the somewhat awkward label counter-presuppositional thetic perfect reflecting the information available from the rich literature that is still somewhat inconclusive as to the true nature of this category (Cyffer and others refer to this category as verb emphasis past). It is not surprising that this category has only emerged in recent times through shift of function: Cyffer (2006: 115, 124) reports the accelerating marginalization of this TAM category from what used to be the general perfective towards a highly specialized function over the last 200 years. Previously theticity has not been described to play a role in the Kanuri system, apart from a short remark by Hutchison (2000: 583) who also states the constitutive absence of focus with this particular category. Ellison (1937) had already observed that "emphasis", i.e. focus, cannot be on other constituents outside the verbal predicate, therefore he speaks of the "predicative force" of this category, supporting Lukas' (1937) “predicative emphasis”, and his label predicative. Clearly, the category in question is part of the PERFECTIVE set, being widely described as “completive” (Hutchison 2000), indicating "achievement” and "accomplishment” (Lukas 1937), or signalling the "factualness of perfective action" (Jarrett 1980). However, there is much more involved than "perfective" aspectual readings, namely that the accomplishment was "unexpected or in spite of difficulty, doubt, initial failure" (Ellison 1937), or is used to "deny existing false expectations or wrong assumptions, whether [...] explicitly stated or not" (Jarrett 1980), or when the action of the verb was achieved "surprisingly, suddenly or recently" (Cyffer 1991). We take all these observations and functional descriptions to be likely circumscriptions of both counter-presuppositionality and theticity.

5 Given our present insights, assertive focus appears to govern the encoding of focus in verbal inflexional morphology, whereas contrastive focus is encoded syntactically (but cf. our discussion of the "Kanuri Focus Anomaly" further below). 
tense, polarity; term focus has scope on subject, object, adjunct, adverb, etc. $^{6}$

- In Kanuri (and in neighbouring Chadic languages, for that matter), there are certain conjugational paradigms available for verbs that encode predication focus with scope on particular operators (aspect, tense), i.e. that have inherent focus, hence we speak of "in-focus" forms; characteristically these "in-focus forms" (often referred to as "absolute" aspects/tenses in traditional terminology) may contrast with "out-of-focus forms" ("relative" aspects/tenses) with whom they share the same verbal aspect (in Kanuri, this would be the Perfective aspect only). The same could be said for the domain of polarity with "negative" operators automatically attracting $[+\mathrm{F}]$ (cf. Table 1 below).

The rich TAM category inventory of Kanuri contains 15 conjugational paradigms, organized in terms of categories such as aspect, tense, and mood, but also categories such as predication focus, counter-presuppositional theticity, syntactic dependency, and polarity. The available grammatical descriptions provide a plethora of competing functional-descriptive labels for the various conjugational paradigms of the verb, for instance, in the descriptions of Koelle (1854), Müller (1877), von Duisburg (1913), Noël (1923), Lukas (1937), Schubert (1970/71), Hutchison (1976), Jarrett (1980), Cyffer (1991, 1998, 2006). Out of these, six paradigms/categories make up the domain of predication focus marking on the verb in the perfective aspect. ${ }^{7}$

6 Note that the theoretically possible category of verb focus (i.e. contrastive focus on the "meaning" of the verbal lexeme) has not been found to be operative in Kanuri. However, for the non-initiated reader there is a source for confusion here: One TAM category is traditionally labelled emphatic, verb emphasis past (but also predicative). The use of the descriptive label "emphasis" may lead one to - falsely - assuming that focus is involved. The label verb emphasis past, however, must be construed within a paired terminology as opposed to noun emphasis past; i.e. it only tells us that it is not a noun or noun phrase that is highlighted in the clause. The label predicative for the same TAM category - rightly indicates that it is not the verb meaning as such that is under "emphasis". The reader is referred to the rich literature on Kanuri grammar. Despite misleading descriptive terminology and inconclusive translations of examples quoted in isolation, therefore, we are not dealing with (contrastive) verb focus.

7 The imperfect does not have inherent focus in the affirmative; predication focus can, however, be assumed to be operative in the negative imperfect on cross-linguistic if not universal grounds, assuming that negation is a predication operator that always attracts focus. 
Table: Non-dependent indicative verb forms in Kanuri

\begin{tabular}{|c|c|c|c|c|c|c|c|c|}
\hline \multirow[t]{2}{*}{ Received labels $^{8}$} & \multicolumn{2}{|c|}{ aspect } & \multicolumn{2}{|c|}{ tense } & \multirow{2}{*}[+\mathbf{PF}]{} & \multirow{2}{*}{ dep. } & \multicolumn{2}{|c|}{ polarity } \\
\hline & $\begin{array}{l}\text { PER } \\
\text { F. }\end{array}$ & IMPERF & pret & fut. & & & aff. & neg. \\
\hline $\begin{array}{l}\text { Noun Emphasis Past [in-focus- } \\
\text { perfect], Aorist, Imperfektum } \\
\text { I, parfait, relative past, relative } \\
\text { perfect, unspecified punctiliar, } \\
\text { noun emphasis completive }\end{array}$ & $\begin{array}{l}+ \\
{[+F]}\end{array}$ & - & - & - & + & - & + & - \\
\hline $\begin{array}{l}\text { Past [preterite in-focus- } \\
\text { perfect], } \\
\text { Imperfektum, Perfektum II, } \\
\text { passé indéfini, past punctiliar, } \\
\text { Historicus }\end{array}$ & + & - & $\begin{array}{l}+ \\
{[+\mathrm{F}} \\
]\end{array}$ & - & + & - & + & - \\
\hline $\begin{array}{l}\text { Dependent past [dependent } \\
\text { preterite in-focus perfect] past } \\
\text { tense of the conjunctional } \\
\text { mood, dep. mood past }\end{array}$ & + & - & $\begin{array}{l}+ \\
{[+\mathrm{F}} \\
]\end{array}$ & - & + & + & + & - \\
\hline $\begin{array}{l}\text { Potential/(Vague) Future } \\
\text { [future in-focus-perfect], Futur, } \\
\text { Eventualis, future punctiliar, }\end{array}$ & + & - & - & $\begin{array}{l}+ \\
{[+F]}\end{array}$ & + & - & + & - \\
\hline $\begin{array}{l}\text { Negative Completive [negative } \\
\text { in-focus perfect], negative past, } \\
\text { Negativus, Negativ }\end{array}$ & + & - & - & - & + & - & - & $\begin{array}{l}+ \\
{[+F]}\end{array}$ \\
\hline $\begin{array}{l}\text { Negative Potential, Future } \\
\text { [negative future], negative } \\
\text { indicative, negative Eventualis, } \\
\text { future negative }\end{array}$ & + & - & - & + & + & - & - & $\begin{array}{l}+ \\
{[+\mathrm{F}]}\end{array}$ \\
\hline $\begin{array}{l}\text { Negative Imperfect, Negative } \\
\text { Indicative, Negative Continuous }\end{array}$ & - & + & - & - & - & - & - & $\begin{array}{l}+ \\
{[+F]}\end{array}$ \\
\hline
\end{tabular}

In the INDICATIVE mood, the salient functional division is one of aspect: Two marked aspectual categories, IMPERFECTIVE and PERFECTIVE, contrast through choice of suffixes. In the IMPERFECTIVE aspect, predication focus is not operational. The PERFECTIVE aspect allows choice of three different suffixes: $\{$-nà $\sim$-ò $\sim$-í\}. The choice of suffix is governed by interaction with predication focus and counter-presuppositional theticity: $\{-1\}$ is used to mark counterpresuppositional theticity, $\{$-nà $\}$ is used to mark [-PF] perfect, and $\{$-ò $\}$ is used to mark $[+\mathrm{PF}]$ perfect. This distinction in terms of suffix function and categorical semantics as reflected in the functional labels that we propose is novel in Kanuri linguistics, but reflect a synthesis of insights that have long been

8 Most recent labels from Cyffer [1998, 2006] in italics, our suggested labels added in [ ] when different. 
held about these TAM categories without, however, recognizing the governing principle behind it.

The Perfective aspect constitutes the heart of the Kanuri verbal inflexional system (see figure 2 below). It interacts with the non-canonical categories of counter-presuppositional theticity, predication focus, and syntactic dependency, and with polarity. The PERFECTIVE is further open to overt marking of tense by prefixing. However, tense marking in the PERfECTIVE is already subject to interaction from the category of predication focus. Compare the following five parallel clause formations: ${ }^{9}$

(1) Affirmative categories in the PERFECTIVE aspect (Hutchison 1981: 125):

a. out-of-focus perfect (perfect in Hutchison 1981)

hàwâr mâi-bè fà-n-gá-nà
news king-GEN hear-AUX-1S-PERF
'I have heard news of the king'

b. $\quad$ in-focus perfect ${ }^{10}$ (noun emphasis completive in Hutchison 1981)
hàwâr
mâi-bè̀ $[+$ TF]
fà-n-g-ô
news king-GEN
hear-AUX-1S-IFP

\section{= hàwâr mâibèmá $[+T F]$ fàngô}

'I heard news of the king'

c. $\quad$ preterite in-focus perfect ${ }^{11}$ (past in Hutchison 1981)

\begin{tabular}{|c|c|c|}
\hline hàwâr & mâi-bè & fà-n-gó-k-ò̀ $[+P F]$ \\
\hline new & king-GEN & hear-AUX-PRET-1S-IFP \\
\hline
\end{tabular}

d. counter-presuppositional thetic perfect (verb emphasis completive in Hutchison 1981)

$\begin{array}{lll}\text { hàwâr } & \text { mâi-bè } & \text { fà-n-g-í } \\ \text { news } & \text { king-GEN } & \text { hear-AUX-1S-CPTP }\end{array}$

'I just heard some news about the king' / 'Have I got some news about the king' / 'Did I ever hear some news about the king'.

9 All tones (high, low and falling) are marked. Morphologically complex forms which are difficult to parse within limited space are indicated by a forward slash.

10 The answer to the question why the "in-focus perfect" as an instantiation of predication focus should mark term focus on the preceding NP will be discussed in detail in section 5 under the notion of the "Kanuri Focus Anomaly".

11 We prefer "preterite" over "past" because in Kanuri literature the term "past" has been indiscriminately used for quite different conjugational paradigms, both for aspect and tense categories. 


\section{$3 \quad$ Predication focus}

Predication focus has become a focal point of interest in African linguistics since Hyman \& Watters' seminal paper of 1984 that refers to this category as "auxiliary focus". This category accounts for the observation that, in some languages and for at least some constructions, the speaker is free to chose between constructions or verb forms marked for predication focus ([+PF]) and those that are not ([-PF]) - here we speak of pragmatic control of focus. In other languages or other constructions within the same language, the speaker has no choice, here grammar enforces the choice between marked [+PF] or [-PF] constructions or verb forms - here we speak of grammatical control of focus. Languages that encode predication focus in their verbal inflexional morphology, therefore, tend to display a subsystem of parallel forms for certain aspectual categories, traditionally referred to as "absolute" vs. "relative" aspect/tense paradigms (for a well-known Chadic language of this type cf. Hausa as discussed in Hyman \& Watters [1984] and again in Wolff [2006]). This leads us to distinguish between (i) in-focus forms, and (ii) out-of-focus forms for at least some of the aspectual and temporal categories. In-focus forms are those marked for [+PF], out-of-focus forms, on the other hand, are those forms that are used when none of the verbal operators is under predication focus (i.e. default [-PF]), irrespective of whether any other clause constituent carries (term) focus or not. In our theoretical approach towards predication focus and following Hyman \& Waters (1984), the in-focus forms of the verbal predicate are said to carry intrinsic focus.

Within the set of in-focus perfect forms, Kanuri makes use of a further subsystem of tense marking through prefixing, thereby allowing for a tripartite system: a tense-less form stands opposed to two morphologically marked tenses, which can be conveniently labelled preterite and future. The latter is, however, according to Hutchison (1981: 118) "the least commonly occurring of the aspects of the language".

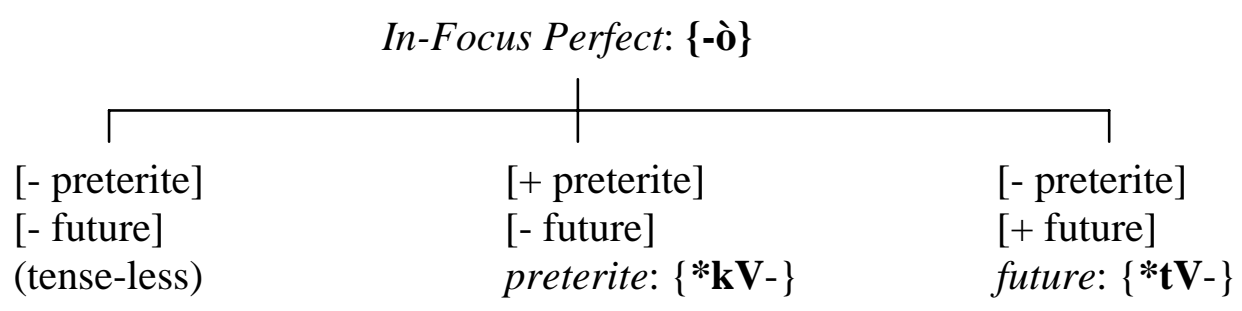

Figure 1: The subsystem of tense marking in Kanuri 
All three conjugational paradigms of the tense subsystem carry the in-focus perfect suffix $\{$-ò . The preterite is additionally marked by a prefix internally reconstructed as $\left\{{ }^{*} \mathrm{kV}-\right\}$, the future is marked by a prefix $\left\{{ }^{*} \mathrm{tV}-\right\}$; both prefixes undergo considerable morphophonological changes in terms of phonetic output and occupy different positions in the morpheme string of the verbal complex depending on verb class. With the exception of the tense-less in-focus perfect (where we note that the noun or noun phrase preceding the verbal predicate can, very often is, and sometimes must be overtly marked for term focus - this will be discussed in detail further below as part of the "Kanuri Focus Anomaly"), [+PF] is clearly on the tense markers in the preterite and the future:

(2) a. Tense-free in-focus perfect (= noun emphasis past in Cyffer 1991: 77)

$\begin{array}{ll}\text { shí-dá-má }[+T F] & \underline{\text { rú-k-ò }} \\ \text { 3S.SP-DET-FOC } & \begin{array}{l}\text { see-1S-IFP } \\ \text { 'I saw him' }\end{array}\end{array}$

b.

Ádò-găi lárdò-dá Fàránsà-yè cú-nót-ò nánkàrò.

DEM-like land-DET French-AG 3S-send-IFP because.of

'That's it, because one sent the French to (rule) the land.' (Löhr in press)

(3) a. Preterite in-focus perfect (= past in Cyffer 1991: 87)

bískà Músà Kánò-rò lè-wó-n-ò $[+P F]$

yesterday Musa Kano-DIR go-PRET-AUX-IFP

'Musa [he] travelled to Kano yesterday'

b.

Háttà kû-rò ká-dé-

until today-ADV PRET-come/3S-IPF

'He used to come until today (and will continue to do so).'

(Löhr in press)

(4) Future in-focus perfect (= future in Cyffer 1991: 149)

dúlì-nóm máárántí-rò yìkkò-m-íyà,

children-POSS school-DIR put/APPL-2S-DFUT

$\begin{array}{lll}\text { kárà-à } & \text { rúwò-à } & \text { cá-l-ò̀ } \\ \text { read-CF] } & \text { write-CO }\end{array}$

'When you put your children into school, they may learn reading and writing' 
In the PERFECTIVE aspect, negation is possible with in-focus perfect forms only, i.e. the in-focus perfect suffix \{-ò\} can be assumed to always precede the infocus perfect negation marker \{-nyí\}. Additional tense marking is allowed, but is restricted to the future. For no practical but purely theoretical reasons, we therefore assume focus to have shifted its scope from aspect to polarity in these examples, thereby avoiding double [+PF] marking, i.e. on both aspect and polarity.

(5) Negative in-focus perfect (= negative completive in Cyffer 1991: 107)

$\begin{array}{ll}\text { sáwà-nyí } & \underline{\underline{\text { ís-ว̀-nyí }}}[+\mathrm{PF}] \\ \text { friend-POSS } & \text { 3S/come-IFP-NEG } \\ \text { 'My friend [he] did not come' } & \end{array}$

(6) Negative future in-focus perfect (= negative future in Cyffer 1991: 150f.)

\author{
cì-làdá-k \\ FUT-sell-1S-IFP-NEG \\ 'I shall not sell (it)'
}

For reasons of space, the subsystem of syntactic dependency as morphologically marked non-canonical inflexional category cannot be treated in any detail in this paper. Two conjugational paradigms specialise on the use in dependent clauses, traditionally known as dependent past and dependent future. Suffice it to say that they appear to be available only in the PERFECTIVE aspect; this analysis is based on the identification of the marking devices which are assumed to contain the markers of both the in-focus perfect and of the counter-presuppositional thetic perfect (cf. Jarrett [1980], Schubert [1971/72]).

The dependent preterite in-focus perfect is derived from the tense-less infocus perfect by an additional suffix \{-nyâ\}, which is added to the in-focus perfect suffix $\{$-ò $\} .{ }^{12}$

12 The in-focus perfect suffix \{-ò\} tends to become deleted on systematic morphophonological grounds in most forms of the paradigm; its underlying presence must be postulated for systemic reasons. It shows up, however, in 3rd pers. forms such as càdônyâ 'when they did', and lèwónònyâ 'when he/she went' (Cyffer 1991: 158, 159). Intriguingly, the previously so-called dependent future appears not to be derived from the in-focus perfect as is the case with the dependent preterite in-focus perfect. As has already been suggested by Jarrett (1980) and Schubert (1971/72), the derivative base appears to be what is now labelled the counter-presuppositional thetic perfect. This analysis would be based on the identification of the suffix $\{-1\}$ as preceding the dependency suffix $\{-[y] a ̀\}$. We, therefore, suggest renaming this paradigm the dependent counter-presuppositional thetic perfect. The apparent contradiction between the two labels (dependent future vs. 
(7) Dependent preterite in-focus perfect (= dependent past in Cyffer 1991: 159)

\author{
búltù kòmówùn cú-r-̂̂-nyâ, káráà-rò cì-yàs-ô \\ hyena elephant 3S/PRET-see-IFP-DPRET bush-DIR 3S/PRET-run-IFP \\ 'When the hyena [he] had seen the elephant, he ran into the bush'
}

(8) Dependent counter-presuppositional thetic perfect (= dependent future in Cyffer 1991: 141)

\begin{tabular}{|c|c|c|c|}
\hline $\begin{array}{l}\text { kúngánà } \\
\text { money }\end{array}$ & $\frac{\text { fàndà-k-íyà, }}{\text { find-1S-DFUT }}$ & $\begin{array}{l}\text { Íngòlà-rò } \\
\text { England-DIR }\end{array}$ & $\begin{array}{l}\text { lè-n-g-în } \\
\sigma 0-A U X-1 S-I M P F R F\end{array}$ \\
\hline
\end{tabular}

The clear hierarchy of categories of verb inflexion in Kanuri, as far as the INDICATIVE mood is concerned, is graphically represented in Figure 2. The figure shows how the subsystem of marking predication focus (highlighted in bold characters) within the PERfECTIVE aspect domain is embedded in the overall structure of the Kanuri TAM system. It shows further that predication focus in Kanuri is operational only in the InDiCATIVE mood in the PERFEctive aspect and in non-thetic clauses; scope encompasses overt verbal operators that relate to aspect, tense and polarity. The overt $[+\mathrm{PF}]$ inflexional marker is the suffix $\{$-ò $\}$ that is shared by 6 verbal conjugational paradigms: 3 affirmative for non-dependent clauses (tense-less IFP, preterite IFP, future IFP), 1 affirmative for dependent clauses (dependent preterite IFP), and 2 negative (negative IFP, negative future IFP). Predication focus, therefore, cannot occur in thetic clauses, neither with the aspect-less sequential, nor in the SUBJUNCTIVE mood. It occurs, however, in both independent and dependent clauses.

dependent [counter-presuppositional thetic] perfect) is explainable in terms of anteriority: a situation or action is set as given and bounded (achieved/accomplished/completed = PERFECTIVE aspect) before another situation or action can/will occur (= future tense). 


\section{VERB INFLEXIONAL MORPHOLOGY}

MOOD

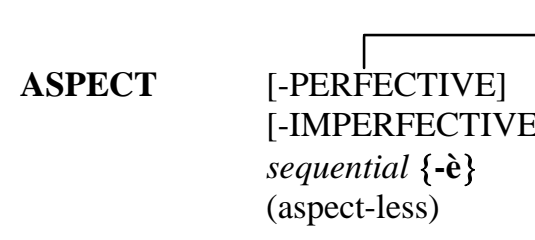

ASPECT

THETICITY

PREDICATION FOCUS
INDICATIVE

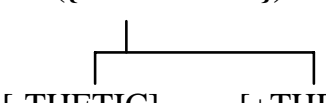

[-THETIC] [+THETIC] counter-presuppositional thetic perfect $\{-\mathbf{i}\}$

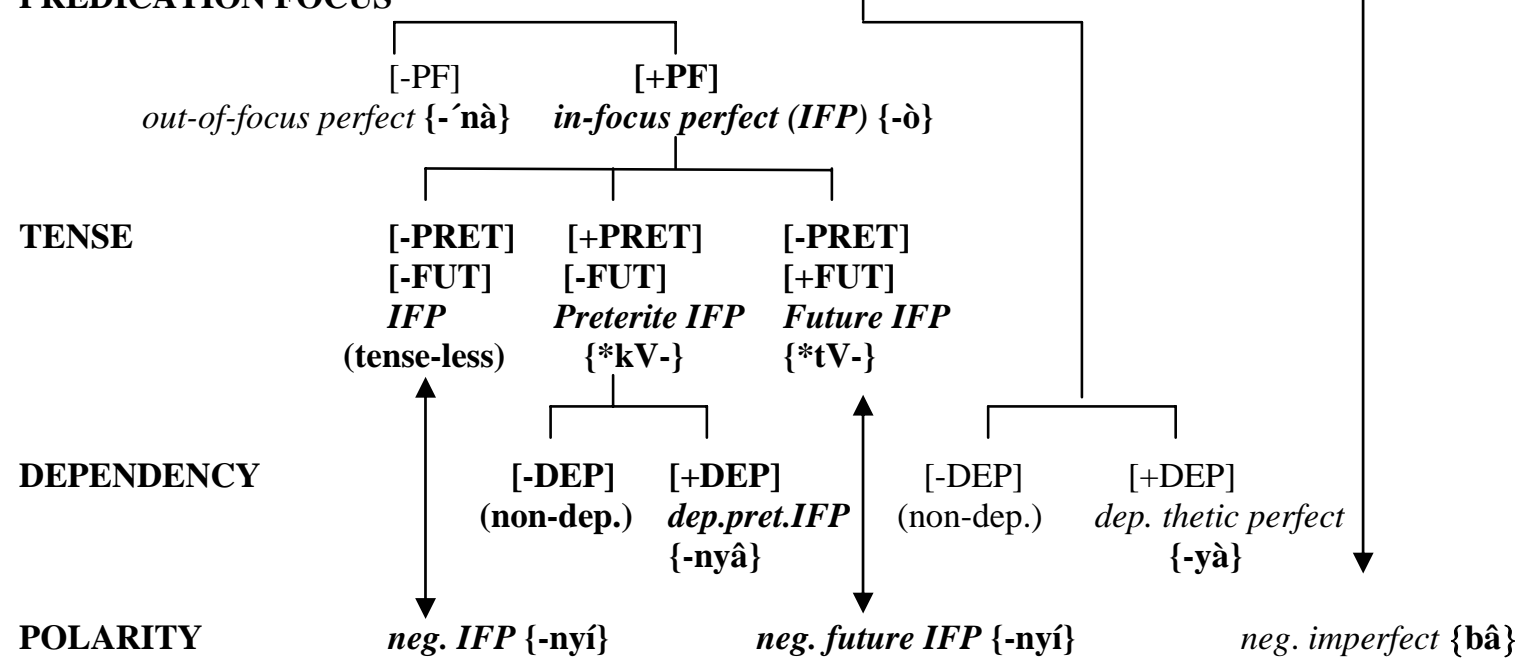

Figure 2: Hierarchy of categories of verbal inflexional morphology

\section{$4 \quad$ Predication focus and other types of focus}

The question whether different focus types can co-occur in one and the same clause in Kanuri cannot be answered in a straightforward manner. The answer invokes issues of dialectology and diachronic changes. Two "simple focus" patterns occur and raise no question as long as only one information component is marked for $[+F]$ :

$$
\begin{aligned}
& \operatorname{TERM}_{[+\mathrm{TF}]}+\operatorname{PREDICATE}_{[-\mathrm{PF}]} \\
& \text { TERM }_{[-\mathrm{TF}]}+\operatorname{PREDICATE}_{[+\mathrm{PF}]}
\end{aligned}
$$

Term focus ([+TF]) is usually marked by clitic \{má\} following the term. We can priori expect a verbal predicate not to be marked for $[+\mathrm{F}]$ at the same time. 
(9) Term focus + out-of-focus perfect (Hutchison 1976: 241)

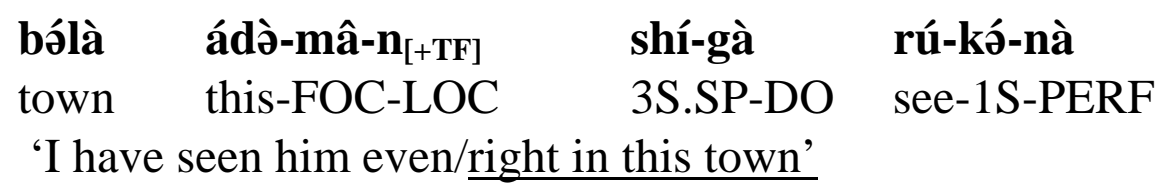
Álì-má ${ }_{[+T F]}$
lè-zó-nà
Ali-FOC go-3S-PERF
'Ali, too, has gone' 'Even Ali has gone'

Term focus can also be expressed by changes of word order (leftward shifting). If so, then the term focus marker \{má\} usually not occurs. Again, we can supposedly expect a verbal predicate not to be marked for $[+\mathrm{F}]$ at the same time.

(10) Term focus on direct and indirect object + imperfect (cf. Cyffer 1991: 281)

$\begin{array}{lllll}\text { Álì } & \text { kákkád̀̀ }_{\text {[+TF] }} & \begin{array}{l}\text { Kánò-làn } \\ \text { Kano-LOC }\end{array} & \begin{array}{l}\text { Músà-rò } \\ \text { Musa-IO }\end{array} & \begin{array}{l}\text { c-în } \\ \text { 3S/give-IMPERF }\end{array} \\ \text { 'Ali will give Musa a book in Kano’ } & & \end{array}$
Álì
Músà-rò̀ $[+$ TF]
Kánò-làn

\section{kákkádò}
c-în
Ali
Musa-IO
Kano-LOC book
3S/give -IMPERF

'Ali will give Musa a book in Kano'

Compare this to the unmarked word order (and no focus marking):
Álì
Kánò-làn
Músà-rò
kákkádə̀
c-în
Ali Kano-LOC Musa-IO book
3S/give -IMPERF
'Ali will give Musa a book in Kano'

Interestingly, our sources testify to the existence of a third strategy to encode term focus, at least and only for subject and direct object noun phrases preceding the verbal predicate. This strategy, and quite surprisingly so, appears to use morphological focus marking on the verb to instantiate term focus on the preceding noun or noun phrase; the verb form being used to achieve this is, appropriate to this function, traditionally labelled noun emphasis past (also known as relative perfect or relative past, which corresponds to our in-focus perfect).

"There is an inter-relationship in Kanuri between the semantics of focus constructions and the morpho-syntax of the aspect of the verb. Among the completive aspects, the Relative Perfect is reserved uniquely for focusing or emphasizing a subject or a direct object noun phrase.” (Hutchison 1976: 241) 
The following examples illustrate that and how term focus appears to be encoded through the verbal paradigm of the tense-less in-focus perfect, irrespective of presence or absence of the overt term focus marker \{má\}. The verb form obviously no longer carries the $[+F]$ feature as is to be expected on a priori grounds.

(11) a. Noun subject and object focus in the in-focus perfect
Álì̀+TF]
lè-z-ô
Álì
-má
lè-z-ô
Ali -FOC
go-3S-IFP
'Ali left (surprisingly, others didn't)'

\begin{tabular}{|c|c|c|c|}
\hline hàwâr & mâi-bè̀ $[+T F]$ & & fà-n-g-ô \\
\hline hàwâr & mâi-bè & -má [+TF & fà-n-g-ô \\
\hline news & king-GEN & $-F O C$ & hear-AUX-1S-IFP \\
\hline
\end{tabular}

The data and descriptions in the sources conflict with the analysis proposed in this paper according to which the verb form labelled in-focus perfect carries $[+\mathrm{PF}]$ marking (hence the new label that we propose). What one would expect is given in (11b), i.e. a contrast between one and two instances of focus in the same clause, provided that we can assume Kanuri to allow both term focus and predication focus to co-occur in the same clause (cf. below).
b. $\quad[+\mathrm{PF}]$ only: $* *$ Álì lèz $\hat{\mathbf{o}}_{[+\mathrm{PF}]}$ [+PF, +TF]: **Álìmá ${ }_{[+\mathrm{TF}]}$ lèzô. $\hat{[}_{[+\mathrm{PF}]}$
'Ali left (surprisingly, others didn't)'
'Ali left (surprisingly, others didn't)'

Either our reanalysis of the traditional noun emphasis past/relative perfect is wrong, or the synchronic situation in Kanuri is more complex than will appear on first sight. We take the latter to be the case and will provide a diachronic explanation of this "anomaly" under the heading of "The Kanuri Focus Shift" in section 5 .

Interestingly, the "anomaly" does not affect the in-focus perfect paradigms that are overtly marked for tense, as in (12). Presence of the term focus marker here is necessary in order to indicate term focus, and obviously [+TF] and [+PF] are allowed to co-occur in the same clause with each marker operating in its proper scope: $\{$ má $\}$ for $[+\mathrm{TF}]$ and $\{$-ò $\}$ for $[+\mathrm{PF}]$. 
(12) Noun subject in the preterite in-focus perfect
Álì lè-wó-n-ò̀
no TF, $[+\mathrm{PF}]$ on preterite operator of verb

Ali go-PRET-AUX-IFP

'Ali left'

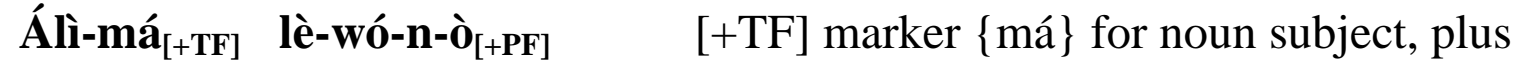 Ali-FOC go-PRET-AUXIFP [+PF] marked for preterite operator of verb 'Ali left'

\section{The Kanuri focus anomaly and the "Kanuri focus shift"}

What we refer to as the "Kanuri Focus Anomaly" is the apparent mismatch of focus marking and focus semantics in certain clauses. This anomaly affects not only interrogative clauses but also clauses that show overt $[+\mathrm{F}]$ marking on the (tense-less) verb $(=[+\mathrm{PF}])$ and the semantics that require us to construe the clause in terms of $[+\mathrm{F}]$ on the overtly unmarked preceding noun phrase (= $[+\mathrm{TF}])$. This anomaly is illustrated once more in (13):

(13) Noun subject and object focus in the in-focus perfect (Yerwa)

\begin{tabular}{|c|c|c|}
\hline focus marking & focus semantics & gloss \\
\hline $\begin{array}{l}\text { Álì lèzố } \hat{[}_{[+F]} \\
\text { hàwâr mâibè fàngô } \hat{\sigma}_{[+F]}\end{array}$ & $\begin{array}{l}\text { Álì̀ }[+F] \\
\text { hàwàr mâô mâibè } \\
{[+F]} \\
\text { fàngô }\end{array}$ & $\begin{array}{l}\text { 'Ali left (surprisingly, others didn't)' } \\
\text { 'I heard news of the king.' }\end{array}$ \\
\hline
\end{tabular}

Informant work on the Manga dialect of Kanuri in Niger revealed some remarkable differences between dialects regarding the scope of focus with the in-focus perfect. In Manga, all in-focus perfect forms, whether marked for tense or not, clearly signal predication focus, and only that, i.e. Manga shows not sign of an anomaly here.

(14) Manga subsystem of the in-focus perfect

tense-less in-focus perfect preterite/ future in-focus perfect ${ }^{13}$

\begin{tabular}{|c|c|c|c|}
\hline wú & rú-k-ò̀ ${ }_{[+P F]}$ & wú & kí-rú-k-ò̀ $[+\mathbf{P F}]$ \\
\hline & see-1S-IFP & 1S.SP & PRET-see-1S-IFP \\
\hline$\underline{\mathrm{sa}}$ & \multicolumn{3}{|c|}{ 'I saw/will see' } \\
\hline
\end{tabular}

13 Note that in Manga the prefixes of the preterite and future tend to be no longer formally distinct and can/must be jointly represented as $\{k i-\}$. 

Álì-gà rú-k- ò
Ali-DO see-1S-IFP
Álì-gà kí-rú-k-ò̀ $[++P F]$
'I saw Ali'
Ali-DO PRET-see-1S-IFP
'I saw/will see Ali'

neg. in-focus perfect neg. pret./fut. in-focus perfect

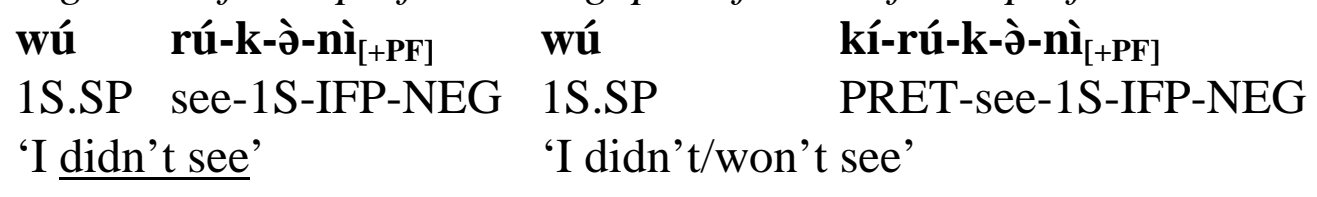
Álì-gà rú-k-ò-nì
Álì-gà kí-rú-k-̀̀-nì̀++PF]
Ali-DO see-1S-IFP-NEG
Ali-DO PRET-see-1S-IFP-NEG
'I didn't see Ali' 'I didn't/won't see Ali'

Compare the Manga situation to Yerwa where, as we saw in (13), the tense-less in-focus perfect form clearly signals focus on the preceding noun phrase. Note that Cyffer (1991), for the Yerwa dialect, always gives the (pronominal) subject of the tense-less in-focus perfect with the term focus marker \{má\} (forms without it would be considered non-grammatical in Yerwa), but does not do so for the preterite (his past) and future; the examples in (15) are from Cyffer (1991: 287, 288). ${ }^{14}$ This again is part of what we call the "Kanuri Focus Anomaly".

tense-less in-focus perfect

$$
\begin{aligned}
& \text { wú-má }{ }_{[+T F]} \text { rú-k-ò } \quad \text { 'I saw (it)' } \\
& \text { 1S.SP-FOC see-1S-IFP }
\end{aligned}
$$

Preterite in-focus perfect wú

1S.SP

Future in-focus perfect

wú

1S.SP

$$
\begin{aligned}
& \text { cú-rú-k-ò̀ }{ }_{[+P F]} \quad \text { 'I saw (it)' } \\
& \text { PRET-see-1S-IFP }
\end{aligned}
$$

$$
\begin{aligned}
& \text { cú-rú-k-ò̀ } \\
& \text { FUT-PF] } \\
& \text { FUee-1S-IFP }
\end{aligned}
$$

Manga allows additional marking of term focus with all the in-focus perfect paradigms, as illustrated in (16). According to our native speaker consultant, the resulting forms have double focus in the preterite/future forms, i.e. [+TF] +

\footnotetext{
14 The preterite and future forms of the in-focus perfect may occasionally turn out homophone in Yerwa like in these examples; in Manga these forms tend to be no longer formally distinct at all.
} 
[+PF], but only one instantiation of $[+\mathrm{F}]$ in the tense-less in-focus perfect, and this is $[+\mathrm{TF}]$. Here the "Kanuri Focus Anomaly" surfaces also in Manga.

(16) Manga in-focus perfect with TF on pronominal subject or noun object (with object marker -gà) tense-less in-focus perfect preterite/future in-focus perfect = only term focus wúmá ${ }_{[+T F]}$ rúkò 'I saw' $=$ double focus wúmá ${ }_{++T F]}$ kírúkò ${ }_{[+P F]}$ 'I saw/will see'

\section{Álìmá ${ }_{[+T F]}$ gà rúkò} 'I saw Álì'

In both dialects it is clearly the tense category that is in the highly localized scope of predication focus when tense is overtly marked. ${ }^{15}$ Note that the positional slot for the overt tense marker varies according to verb class. Examples in (17) are from the Manga dialect.

verb class 1 Preterite

Future

Future

verb class 2 Preterite

\section{Álì}

cí́ $\left.{ }_{[+P F}\right]^{-n o ́ t}-\grave{o}$

'Ali sent' PRET/3S-send-IFP

Álì

cí $[+$ +PF]-nót-ò FUT/3S-send-IFP

'Ali will send'

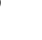

Álì

lè-wó ${ }_{[+P F]}-\mathbf{n}-\mathbf{o}$

'Ali went' go-PRET-AUX-IFP

Álì
'Ali will go'

In the tense-less in-focus perfect, however and in both dialects, the situation is different. Quite against expectations for the use of interrogatives, for instance, the clause predicate must occur in the in-focus perfect. Also, the answer to interrogatives requires the in-focus perfect, as shown in the Manga example in (18a), but not the term focus marker \{má\}. In the light of cross-linguistic if not universal patterns where focus is generally assumed to be on the interrogative

15 With certain verbs, overt distinction between preterite and future remains possible. In the following examples under (17), we indicate the presumed exact focus location by [+PF] following the tense slot in the morphological structure of the verb. 
and on the interrogated noun in the answer to the question we notice another instance of the "Kanuri Focus Anomaly", as in (18b). Based on theory-guided expectation, we are now forced to assume the "anomalous" situation given in (18c). This anomaly again will be accounted for by the "Kanuri Focus Shift" discussed further below.
a. Q: wùndú lèjôj $\hat{[+F]}_{\text {? }}$ ?
'Who left?'
(Not acceptable: out-of-focus perfect ** wùndú lèzánà?)
A: Álì lèjồ $\hat{[+F]}$
'Ali left'
b. Q: wùndú $[+F]$ lèjô?
'Who ${ }_{[+F]}$ left?'
A: Álì $+F]$ lèjô
'Ali [+F] $_{\text {left' }}$
C. Q: wùndú lèjô $\hat{\text { }}_{[+F]}$ ?
A: Álì lèjô $\hat{\text { otF] }}_{[}$
'Who ${ }_{[+F]}$ left?'
'Ali $i_{[+F]}$ left'

Still in Manga: When uttered in isolation, or in answer to the question "what has happened?”, the interpretation of the appropriate answer Álì lèjô 'Ali left' in terms of focalised elements poses considerable problems for the speaker, who after lengthy contemplation and phonetic contrast with similar forms and constructions settles (and does so consistently on different occasions) on a double focus marking analysis as presented in (19), particularly in comparison to (20) where term focus is overtly marked and the speaker clearly identifies the noun subject (and only the noun subject!), to be in focus. Again, the "Kanuri Focus Anomaly" is at work: it extends $[+F]$ from the verb onto the preceding noun in (19), and it removes [+F] from the verbal operator in (20) where [+TF] is overtly marked by $\{$ má $\}$ :

$$
\begin{aligned}
& \text { Álì̀ }{ }_{[+F]} l e ̀ j \hat{o}_{[+F]} \quad \text { 'Ali left' } \\
& \text { Álìmá }{ }_{[+F]} \text { lèjồ 'Ali left' }
\end{aligned}
$$

In the Yerwa dialect, the tense-less in-focus perfect clearly signals term focus on the preceding noun or noun phrase (subject or direct object) even in the absence of overt [+TF] marking by \{má\} as in (21), hence its traditional label as "noun emphasis past”. The verbal predicate, however, loses its original $[+\mathrm{F}]$ properties.

(21) Yerwa: [+TF] on preceding noun phrase in tense-less in-focus perfect

$$
\begin{array}{ll}
\begin{array}{l}
\text { Álì̀ } \\
\text { hàwF] lèzồ mâibè̀ } \\
\text { hâTF] }
\end{array} \text { fàngôô } & \text { 'Ali left' } \\
\text { 'I heard news of the king', cf. (1b) }
\end{array}
$$


In the Manga dialect, at least with our language consultant, the situation is not quite as clear-cut as in Yerwa because [+F] appears to remain semantically active on the predicate despite being extended in scope to the subject that is otherwise unmarked for [+TF], so (19) is acceptable, even if (20) may be preferred for its lack of ambiguity.

Looking at the "Kanuri Focus Anomaly" in Manga and Yerwa, we arrive at a picture that reminds one of "floating tones" in autosegmental phonology. Borrrowing autosegmental terminology, we could say that in the Kanuri tenseless in-focus perfect, the scope of focus is "associated" with the PERFEctive aspect operator, i.e. the verbal suffix $\{$-ò $\}$. With tense being overtly marked somewhere to the left of the verbal suffix $\{$-ò $\}$, the scope of $[+\mathrm{PF}]$ becomes "disassociated" from the suffix in order to be "re-associated" with the tense marker further to the left. And here is where we assume diachronic processes to come into play: Once this leftward shifting strategy is established, the tense-less in-focus perfect undergoes re-analysis. Since focus on ZERO is counterintuitive, to say the least, it would not be surprising for the language to shift the scope of focus still further and again in leftward direction. This means that in the absence of an overt tense marker to the left of the suffix, the scope of focus "jumps" not only the empty tense marking slot but also the left word boundary of the verbal complex - and ends up on the noun phrase immediately preceding the verb. This can be represented as in (22); the examples also show the different position of the tense marker slot. ${ }^{16}$

(22) Double leftward shifting of scope of focus with tense-less in-focus perfect

\begin{tabular}{|c|c|c|c|c|}
\hline \multirow[t]{2}{*}{ verb class } & \multicolumn{3}{|c|}{$[+\mathrm{F}]$ associated with /localized on } & \multirow[t]{2}{*}{ gloss } \\
\hline & aspect suffix & tense marker & preverbal NP & \\
\hline verb class 1 & *Ali sú-nót-ò̀ ${ }_{[+F]}$ & $*$ Ali sú- $\varnothing_{[+F]}-$ nót-ò & $\mathrm{Ali}_{[+\mathrm{F}]}$ súnótò & Ali sent \\
\hline verb class 2 & *Ali lè-z-'- $\grave{o ̀}_{[+F]}$ & *Ali lè-z- $\varnothing_{[+F]^{-}-\mathbf{o ̀ ~}}$ & $\mathbf{A l i}_{[+\mathrm{F}]}$ lèzô & Ali went \\
\hline
\end{tabular}

The three diachronic stages of this leftward "Focus Shift" can be illustrated from the two dialects, cf. Figure 3. At the final stage (represented by the Yerwa situation), we can state that the original predication focus that was localized originally on the aspect operator (the PERFECTIVE suffix \{-ò\}) has shifted both

16 This slot has different positions in the verbal complex depending on verb class: it is a prefix to the verb root in verb class 1 , but follows the so-called "meaning carrier" morpheme and precedes the "conjugational base" *-n- in verb class 2 . The *-n- may, however, be deleted on systematic grounds; it could be said to leave a trace in the shape of the polar tone that is realised as part of a falling contour on the final syllable: lèzô. 
position, i.e. leftward from verb suffix to preverbal noun or noun phrase, and type, i.e. from $[+\mathrm{PF}]$ to $[+\mathrm{TF}]$, also involving shift from assertive focus to contrastive focus.

\begin{tabular}{|c|c|c|c|}
\hline 1 & Manga & $\begin{array}{l}\text { wú rúkò̀ } \\
\text { Álì lèjồ } \\
{[+P F]}\end{array}$ & $\begin{array}{l}\text { I } \underline{\text { saw }} \text { ] } \\
\underline{\text { Ali went (answer to question: “Who went?”) }}\end{array}$ \\
\hline 2 & Manga & Álì ${ }_{[+T F]} l e ̀ j \hat{o}_{[+P F]}$ & $\begin{array}{l}\text { Ali left (in isolation, answer to question "What } \\
\text { happened?") }\end{array}$ \\
\hline 3 & Yerwa & Álì̀ ${ }_{[+T F]}$ lèzô & Ali left \\
\hline
\end{tabular}

Figure 3: Graphic representation of the "Yerwa Focus Shift"

The observation that Manga represents a more archaic stage and Yerwa the most advanced stage of this grammatical change supports Cyffer's (2006) claim that the northern varieties (like Manga) are changing at a slower pace than the central varieties (to which Yerwa belongs). The "Kanuri Focus Shift" accounts for statements in the literature as the following which relate to the verb form that we call the tense-less in-focus perfect and which is used to indicate "... semantic prominence for one of the major constituent noun phrases, i.e. either the subject or the object noun phrase” (Hutchison 1981: 126f.):

"This past tense gives prominence to some particular word in the sentence which is distinct from the idea contained in the verb. The emphasis is never on the verb itself." (Ellison 1937: 87 on his "Relative Past”)

"With this paradigm, the focus is shifted away from the event described by the verb to a nominal phrase within the same clause. Thus the Unspecified Punctiliar can never stand alone as a complete sentence; there must always be a stressed nominal phrase with it. This prefixless paradigm is the basic, neutral form of the Punctiliar, thus allowing all possible attention to be focussed on the nominal phrase.” (Jarrett 1980: 8)

Once we have accepted the idea of a diachronic leftward dislocation process that shifted scope of focus from the verb to the preceding noun phrase, we still need to account for the shift of focus type from assertive [+PF] to contrastive [+TF]. A straightforward answer would be to say that this follows automatically from the leftward dislocation: once focus ends up on the "term" represented by that noun phrase, "TF" interpretation would be the only plausible and natural consequence, and TF in Kanuri always means contrastive focus. In a more formalistic manner, one could argue that we are dealing with some kind of "focus overload" that calls for "focus overload reduction". The starting point of the "Kanuri Focus Shift" would be the situation that we still find in both Manga and Yerwa, namely the combined marking of predication focus and term focus, cf. examples of the preterite in-focus perfect in (23). The scope of the [+PF] marker $\{$-ò $\}$ is on the overt tense marker of the preterite, and \{má\} marks [+TF] on the preceding noun phrase. (cf. ex. (12) and (1c)) 
In the case of the tense-less in-focus perfect in combination with term focus on the preceding noun phrase, however, we have argued that the scope of the [+PF] marker remains somewhat "floating" over the verb form since it cannot localize due to the absence of an overt tense marker, so it becomes dislocated even further to the left and across the next left word boundary. This would lead to some kind of "focus overload" on the NP preceding the verbal predicate when the NP is already overtly marked for [+TF], as illustrated in (24) for Manga.

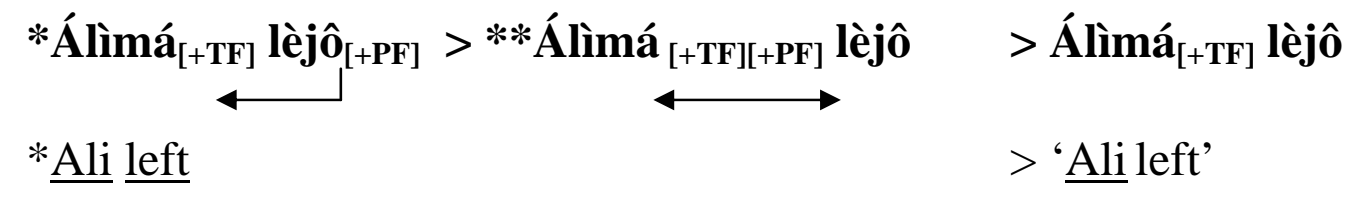

The intermediate cumulative effect (resulting, theoretically, in the combination of the features $[+\mathrm{TF}]$ plus $[+\mathrm{PF}]$ on a preverbal noun phrase) may have triggered the reduction of the semantically improbable double and heterogeneous focus properties of the NP to the more natural and semantically plausible simple [+TF] property. Consequently, the tense-less in-focus perfect (= an instantiation of predication focus) thereby looses its intrinsic [+PF] property in this particular environment by a language-internal re-analysis as "noun emphasis past" (= an instantiation of term focus) in traditional Kanuri grammar terminology. By generalization of this grammatical change, the tense-less in-focus perfect may now co-occur with preceding NPs that are unmarked by the $[+\mathrm{TF}]$ marker $\{$ má $\}$, and still the clause is interpreted to contain term focus on the NP - simply by collocation with the tense-less in-focus perfect, as illustrated again in (25).

(25) *Álì lèz $\hat{\mathbf{o}}_{[+\mathbf{P F}]} \quad>\quad$ Álì ${ }_{[+\mathrm{TF}]}$ lèzôo 'Ali left'

The tense-less in-focus perfect still likes to co-occur with term focus marking devices, in Yerwa Kanuri possibly to a much greater extent than in Manga Kanuri. This is reflected, for instance, in the following grammatical description for Yerwa (Cyffer 1991: 77):

"The noun emphasis past is used, when (a) the action is completed or has started, and (b) a major constituent noun phrase - subject or direct object - is focussed.

Focus is often expressed by the emphatic suffix -má, e.g. málàmndémá Màidùgùrírò lèzôo our teacher went to Maiduguri 
sàndímá shígà sórò shídə̀má rúkò they saw him

I saw him"

It is the "Kanuri Focus Shift" that also accounts for the "anomaly" already illustrated from Manga in (18) above, namely the counter-intuitive cooccurrence of the (tense-less) in-focus perfect with generally $[+\mathrm{F}]$ marked interrogatives (and answers to interrogatives). Since the same situation prevails in Yerwa, relevant Kanuri grammars give functional descriptions like the following (Cyffer 1991: 77):

"Interrogatives in the subject and direct object position are considered in Kanuri as focus constructions. Therefore the noun emphasis past is used in completed actions.

Ndú ísò?

ndú rûm?

àbí sòdô?

kàkkàdə̀bí ràâm?
Who came?

Whom did you see?

What did he/she do?

Which book do you like?”

It is the "anomalies" stemming from the diachronic "Kanuri Focus Shift" (which itself may well be part of the considerable grammatical change affecting the Kanuri TAM system in general and the PERFECTIVE aspect domain in particular, cf. Cyffer 2006) that has until now prevented linguists to (a) identify one (and only one) common function for the verb inflexional suffix \{-ò\}, and (b) recognize the existence of a neat subsystem of innovative predication focus marking in Kanuri. ${ }^{17}$

\section{Summary and conclusion}

The rich inflexional morphology of the Kanuri verb was reviewed in terms of its potential to encode information structural properties, and the relevant descriptive literature and discourse material was scrutinized along these lines. This has led us, among other things, to identify the clear-cut distinction between in-focus and out-of-focus forms in the PERFECTIVE aspect domain where $[+\mathrm{PF}]$ is morphologically marked by the suffix $\{$-ò $\}$. On the level of clause syntax, we were able to analyse and explain certain "anomalies" in the behaviour of focus in Kanuri in terms of grammatical changes that we refer to as the "Kanuri Focus

17 The unique function of the suffix $\{$-ò $\}$ was also veiled behind inconclusive terminology in the labelling of the inflexional categories, see table 1 . Who would have assumed that there was a common functional category being marked behind apparently heterogeneous TAM category labels in the affirmative, plus two negatives and one syntactically dependent form, and that the uniting morphological and semantic element was predication focus? 
Shift". Whether and how the development of encoding predication focus in Kanuri grammar is the result of language contact, in particular with surrounding Chadic languages, remains to be discussed and presented at another occasion (cf. Wolff \& Löhr, in prep.). 


\section{$7 \quad$ References}

Cyffer, N. (2006) Perceptions of time and their conceptualisation in Saharan languages. In: B. Caron \& P. Zima (eds), Sprachbund in the West African Sahel. Collection Afrique et Langage, 11. Selaf no. 432. Louvain-Paris: Peeters, 113-128.

Cyffer, N. (1998) A Sketch of Kanuri. Cologne: Köppe.

Cyffer, N. (1991) We Learn Kanuri. Cologne: Köppe.

Duisburg, A. von (1913) Grundriß der Kanuri-Sprache in Bornu. Berlin: Reimer.

Ellison, R. E. (1937) An English-Kanuri Sentence Book. London: OUP.

Güldemann, T. (1996) Verbalmorphologie und Nebenprädikation im Bantu. Bochum: Universitätsverlag Dr. N. Brockmeyer.

Hutchison, J. P. (2000) Predicate Focusing Constructions in African and Diaspora Languages, In: Wolff, H. E. \& O. D. Gensler (eds) Proceedings of the 2nd World Congress of African Linguistics, Leipzig 1997. Cologne: Köppe, 577-591.

Hutchison, J. P. (1981) A reference grammar of the Kanuri language. Madison: University of Wisconsin; [Boston]: African Studies Center, Boston University.

Hutchison, J. P. (1976) Aspects of Kanuri Syntax. Unpubl. PhD Thesis (Indiana University). University Microfilms International.

Hyman, L. \& J. R. Watters (1984) Auxiliary focus. Studies in African Linguistics 15 (3): 23373.

Jarrett, K. A. (1980) Tense/aspect/mood in Kanuri verb forms. Harsunan Nijeriya 10: 1-28.

Koelle, S. W. (1854) Grammar of the Bornu or Kanuri Language. London: CMS.

Löhr, D. (in press) Predication focus in Malgwa. In: H. Tourneux (ed.) Proceedings of the 3rd

Biennial International Colloquium on the Chadic Language Family Paris 2005, Cologne: Köppe.

Löhr, D. (in press). Nigerian Kanuri (Sub-)Dialects Reconsidered - a Corpus-based Approach. - In: Reh, M. \& D. Payne (eds.) Proceedings of the 7th Nilosaharan Conference, Hamburg, August 22-25th 2001. Cologne: Köppe.

Lukas, J. (1937) A Study of the Kanuri Language. London: OUP.

Müller, F. (1876-77) Grundriss der Sprachwissenschaft Vol. I, Die Kanuri-Sprache, 192-214. 4 vols. Wien: Alfred Hölder.

Noël, P. (1923) Petit manuel français - kanouri. Paris: Geuthner.

Schubert, K. (1971/72) Zur Bedeutung und Anwendung der Verbalparadigmen im Hausa und Kanuri. Afrika und Übersee 55: 1-49, 208-227, 267-300; 56: 90-118.

Wolff, H. E. (in press) The impact of clause types and focus control, aspect, modality, and referentiality on negation in Lamang and Hdi (Central Chadic). In: N. Cyffer (ed.) Negation Patterns in West Africa.

Wolff, H. E. (2006) Intrinsic Focus and Focus Control in two varieties of Hausa. In: E. Voeltz (ed.) Studies in African Linguistic Typology, Amsterdam - Philadelphia: Benjamins. 
Wolff, H. E. (2003) Predication Focus in Chadic Languages. In: H. E. Wolff (ed.) Papers in Chadic Linguistics. From the 1st Biennial International Colloquium on the Chadic Language Family, Leipzig 2001. Cologne: Köppe, 137-159.

Wolff, H. E. (1983) A Grammar of the Lamang Language (Gwàd Làmàn). Glückstadt: J. J. Augustin.

Wolff, H. E. \& D. Löhr (in prep.) Convergence in Saharan and Chadic TAM Systems. In: Afrika und Übersee Special volume: Johannes Lukas (1901-1980) - 25th anniversary of his death. 